\title{
PERTANGGUNGJAWABAN NOTARIS DALAM PEMBUATAN AKTA PENGIKATAN JUAL BELI
}

\author{
Ni Kadek Septiarianti, I Nyoman Sumardika, Ni Gusti Ketut Sri Astiti \\ Fakultas Hukum Universitas Warmadewa, Denpasar - Bali, Indonesia
}

\begin{abstract}
Abstrak
Notaris merupakan pejabat umum yang memiliki jabatan mulia dan dalam membuat setiap akta seorang notaris mempunyai tanggung jawab yang besar sehingga tidak boleh terjadi kesalahan. Penelitian ini bertujuan untuk mengetahui tanggungjawab notaris dalam pembuatan akta pengikatan jual beli yang belum lunas dan mengetahui akibat hukum terhadap pengikatan akta jual beli yang belum lunas. Penelitian ini menggunakan metode penelitian hukum normatif. Sumber data yang digunakan adalah Undang-undang atau hukum sebagai data primer (Data utama). Teknik analisis data yang digunakan adalah teknik argumentasi dan teknik sistemalisasi. Hasil analisis menunjukan bahwa Pertanggungjawaban notaris sebagai pejabat umum saat pembuatan akta pengikatan jaul beli yaitu bertanggung jawab secara hukum administrasi, hukum perdata, hukum pidana dan kode etik profesi notaris. Semuanya, tentu, berdasarkan pada hubungan hukum yang terjadi antara PPAT dengan para pihak yang menghadap saat pembuatan akta tersebut. Pertanggungjawaban dari sanksi administrasi yaitu peringtan lisan, peringatan tertulis, pemberhentian sementara, pemberhentian dengan hormat bahkan sampai pemberhentian tidak hormat. Selanjutnya untuk sanksi perdata yaitu berupa penggantian biaya atau ganti rugi dan juga bunga. Sedangkan sanksi pidana yang dapat dipertanggungjawabkan kepada seorang notaris/PPAT adalah apabila penipuan itu bersumber dari notaris/PPAT itu sendiri untuk sanksi pidana bisa diberikan dengan meninjau dahulu apakah notaris/PPAT itu memenuhi isi rumusan dari tindak pidana yang disangkakan. Selain dari ketiga sanksi diatas, baik dari segi hukum adiminstrasi, perdata hingga pidana notaris/PPAT yang pastinya juga bertanggung jawab peenuh secara sadar terhadap kode etik notaris, yang juga membuat notaris/PPAT bertanggung jawab atas sanksi berupa yaitu: teguran, peringatan, skor, hingga pemecatan dari keanggotan dan pemberhentian dengan tidak hormat.
\end{abstract}

Kata Kunci: Pertanggungjawaban; Notaris; Perjanjian; PPAT

\begin{abstract}
Notary public is a public official who has a noble position and in making every notarial deed a great responsibility so that no mistakes can occur. This study aims to determine the responsibility of a notary public in making a purchase agreement binding that has not been settled and to know the legal consequences of binding the purchase agreement that has not been paid in full. This research uses normative legal research methods. The data source used is the law or law as primary data (main data). The data analysis technique used is the argumentation technique and systemalization technique. The results of the analysis show that the responsibility of a notary public as a public official when making a deed of binding purchase agreement that is responsible for administrative law, civil law, criminal law and the code of ethics of the notary profession. Everything, of course, is based on the legal relationship that occurs between the land deed official and the parties facing when making the deed. Accountability for administrative sanctions is verbal warning, written warning, temporary dismissal, respectful dismissal even to disrespectful dismissal. Next to civil sanctions in the form of reimbursement or compensation and interest. Whereas a criminal sanction that can be accounted for by a notary/land deed official is if the fraud originated from the notary/land deed official itself for criminal sanctions can be given by first reviewing whether the notary / land deed official meets the contents of the formulation of the alleged crime. Apart from the three sanctions above, both in terms of legal, administrative, civil to criminal notary/land deed official which is certainly also responsible for conscious fulfillment of the notary code of ethics, which also makes the notary / land deed official responsible for sanctions in the form of: reprimand, warning, score, to dismissal from membership and dismissal with no respect.
\end{abstract}




\section{PENDAHULUAN}

Di Indonesia tanah adalah hal yang penting untuk berlangsungnya kehidupan. Karena bagi rakyat Indonesia selain air, tanah pun merupakan sumber kehidupan untuk bercocok tanam sehinggadewasainiperalihanhakatastanahtidak pernah berhenti dan dari beberapa tahun terakhir ini penjualan tanah tidak pernah sepi karena selain dimanfaatkan untuk keperluan pribadi tanah juga digunakan sebagai investasi yang menguntungkan, itu karena setiap tahun selalu terjadi kenaikan terkait harga tanah dan jika terjadi jual beli hak atas tanah kita harus menghadap ke Notaris/Pejabat Pembuat Akta Tanah (untuk selanjutnya disebut PPAT). Dalam UUJN dijelaskan Notaris/PPAT merupakan pejabat umum yang berwenang untuk membuat akta autentik dan memiliki kewenangan lainnya sebagaimana dimaksud dalam undang-undang ini atau berdasarkan undang-undang lainnya.

Seorang notaris didalam menjalankan jabatannya harus dapat bersikap profesional dan jujur sesuai dengan kode etik profesi seorang Notari sagar notaris mendapat kepercayaan dari masyarakat. Notaris harus memiliki etika yang baik dalam menjalankan tugasnya karena jika seorang notaris tidak memiliki etika yang baik maka bisa saja dalam menjalankan tugasnya notaris meyalahi aturan sehingga bisa dikenakan sanksi baik administrasi, perdata hingga pidana. Sehingga sebelum notaris diangkat menjadi pejabat umum harus bersumpah terlebih dahulu dan oleh karena itu dalam melaksanakan kewenangannya notaris harus selalu ingat dengan sumpahnya dan tunduk dibawah undang-undang yang berlaku.

Jabatan seorang notaris/PPAT merupakan jabatan mulia karena notaris/PPAT merupakan perpanjangan tangan dari pemerintah, notaris/PPAT disebut pejabat umum yang memberikan pelayanan hukum atau edukasi secara gratis kepada masyarakat, itulah mengapa disini peran notaris tidak boleh diremahkan atau dipandang sebelah mata. Orang yang datang kehadapan notaris/PPAT sudah pasti memiliki tujuan tertentu dan yang pasti berbeda-beda tetapi masalah yang akan diangakat dalam pembahasan skripsi ini yaitu terkait Akta Jual Beli/AJB yang dibuat dihadapan notaris/PPAT. Tetapi sebelum AJB dibuat para pihak yang mengadap ke Notaris/PPAT harus diingkat dulu dengan Perjanjian Pengikatan Jual Beli/PPJB. PPJB itu ada 2 jenis, yaitu PPJB yang sudah lunas pembayarannya dan PPJB yang belum lunas dan sesuai dengan judul yang akan diabahs disini adalah PPJB yang belum lunas. Tujuan dibuatnya PPJB yaitu sebagai bentuk pengikatan kedua belah pihak, artinya agar tidak terjadi hal yang tidak diinginkan jadi harus ada pengikatan yang jelas karena bisa saja salah satu pihak ada yang ingkarjanjisehinggapihakyanglaindirugikanjadiuntukmenghindarihal tersebut PPJB harus dibuat terlebih dahulu, itulah mengapa peran notaris/PPAT disini sangat dibutuhkan untuk memberikan edukasi kepada para pihak terkait PPJB yang akan dibuat walapun isi dari PPJB itu merupakan keinginan kedua belah pihak namun notaris/PPAT yang akan memantau apakah isi dari PPJB tersebut sudah sesuai dengan aturan udndang-undang.

Terkait dengan Perjanjian/Pengikatan itu sendiri prosedurnya sudah ada dalam KUH Perdata tentang pengertian pengikatan, syarat sahnya pengikatan dan lain sebagaianya. Dan disini pertanggungjawaban noatris/PPAT yang dimaksud adalah terkait prosedur yang dijalankan dalm proses pembuatan PPJB hingga AJB tersebut. Apabila akta pengikatan jual beli atas tanah yang ditanda tangani dan dibuat oleh Notaris/PPAT ada kekeliruan, tidak sesuai dengan tata cara pembuatannya, maka Notaris memiliki tanggungjawab secara hukum terhadap siapa dan kepada siapa akta perjanjian jual beli dibuatnya, dan apabila Notaris terbukti melakukan kesalahan baik disengaja maupun tidak disengaja, maka akibat hukum yang timbul dapat dikenakan sanksi sesuai dengan tingkat kesalahan atau kekeliruan terhadap akta pengikatan jual beli yang dibuatkan seorang Notaris/PPAT dapat dikenakan sanksi meliputi sanksi administrasi, sanksi perdata, sanksi pidana maupun kode etik profesi jabatan Notaris.

Perjanjian Pengikatan Jual Beli (untuk selanjutnya disebut PPJB) digunakan untuk melakukan pengikatan sebelum pembuatan Akta Jual Beli (untuk selanjutnya disebut AJB) yang resmi di hadapan notaris/PPAT. Apabila dalam pembuatan pengikatan perjanjian jual beli Notaris/PPAT haruslah memberikan perhitungan terhadap pajaknya. Notaris bertanggungjawab terhadap melakukan pemotongan terhadap Pajak penghasilan dan bea perolehan hak atas tanah dan bangunan (BPHTB), dan melakukan pembayaran melalui Direktorat Jenderal pajak.

Apabila terjadi kelalaian dalam pembuatan AJB yang telah dibuat, maka Notaris mempunyai kewajiban yang berkaitan dengan sumpah/janji notaris yang menyebutkan Notaris harus merahasiakan isi dari akta dan juga semua keterangan yang diperoleh saat menjalankan profesi notaris. Jadi apapun yang terjadi seorang notaris harus dapat melaksanakan sumpah selama menjadi pejabat umum. 
Beberapa penelitian terkait dengan isu saat ini telah dilakukan sebelumnya seperti Muyassar, Ali, \& Suhaimi (2019); Rosadi (2020); Santyaningtyas \& Zubaidi (2020); Sujana, Renaya, \& Prapta (2019); Wulandari (2019) mengkaji tentang pertanggungjawab Notaris terhadap jual beli. Namun, perberdaan dengan penelitian saat ini lebih berfokus pada pengikat jual beli yang belum lunas. Oleh karena itu, tujuan penelitian baru ini untuk mengetahui tanggungjawab notaris dalam pembuatan akta pengikatan jual beli yang belum lunas dan mengetahui akibat hukum terhadap pengikatan akta jual beli yang belum lunas.

\section{METODE PENELITIAN}

Tipe penelitian yang digunakan adalah tipe penelitian hukum normative (Suratman \& Philips Dillah, 2012). Adapun tipe pendekatan permasalahan yang digunakan untuk membahas permasalahan dalam penelitian ini yaitu berdasarkan sumber hukum pustaka, peraturan perundang-undangan maupun pandangan dari ahli hukum. Bahan hukum primer yang digunakan bersumber dari UUD NKRI 1945, Undang - Undang No. 30 th 2014, dan Undang - Undang No. 2 thn 2014 tentang Perubahan atas Undang - Undang No. 30 Tahun 2004 tentang Jabatan Notaris, Lembaran Negara Republik Indonesia tahun 2016 Nomor 180, Tambahan Lembaran Negara Republik Indonesia Nomor 549. Serta ada juga bahan hukum sekunder yang bersumber dari literatur, tesis, buku- buku, dan lain sebagainya.

\section{HASIL PENELITIAN DAN PEMBAHASAN}

\section{Akibat Hukum terhadap Pengikatan Akta Jual Beli Belum Lunas Dipersalahkan}

Selanjutnya akibat hukum untuk peralihan hak milik/HM atas tanah yang belum lunas pembayarannya yaitu tetap sah secara jual beli, hanya saja jika pembayaran tanahnya belum dilunasi dahulu maka peralihan dari haknya itu dapat ditangguhkan yang juga sesuai dengan PPJB lunas. Jika pembayaran sudah dapat dilunasi semuanya baru proses dari peralihan terkait haknya bisa dilanjutkan yaitu pembuatan AJB dan proses sertifikatnya. Untuk syarat dari jual beli ada 2, yaitu materiil dan formiil. Kedua syarat tersebut harus dipenuhi oleh PPAT.

Untuk dapat melihat adanya kepastian hukum terkait peralihan hak tanah, berdasarkan PP No. 24 tahun 1997 tentang peraturan pelaksanaan UUPA menjelaskan bahwa: "setiap perjanjian yang bermaksud memindahkan hak atas tanah harus dibuktikan dengan suatu akta yang dibuat oleh dan dihadapan PPAT". Oleh karena itu, disini notaris/PPAT mempunyai peran sangat penting terkait pelaksanaan peralihan hak atas sebidang tanah. Notaris/PPAT yang telah membuat AJB, setelah itu aktanya dapat digunakan sebagai alat bukti yang isinya menerangkan telah terjadi suatu pemindahan hak atas tanah yang dilakukan melalui jual beli. Jadi dapat disimpulkan bahwa disini PPAT sangat berperan penting terkait peralihan/pemindahan hak milik atas tanah yang belum lunas pembayarannya, karena dihadapan notaris/PPAT perjanjian pengikatan jual beli tersebut dibuat. Walaupun poin dari perjanjian yang dituangkan dalam isi akta tersebut ditentukan oleh para pihak penghadap, tetapi notaris/PPAT tetap bisa menjadi penentu apabila ada keinginan dari para pihak tersebut yang bertentangan/melanggar peraturan yang berlaku.

\section{Faktor-faktor Penyebab Pengikatan Akta Jual Beli Belum Lunas}

Terkait pembahasan diatas jadi ada faktor yang mendorong terjadinya peralihan hak atas sebidang tanah yang belum lunas terkait dengan pembayarannya diantaranya, yaitu:

1. Bisnis, karena di masa sekarang ini bisnis property merupakan bisnis yang paling menjanjikan untuk digeuti, saat ini semua developer sudah pasti berlomba untuk membeli tanah dengan posisi strategis yang selanjutnya dikembangkan lagi dan dijual kembali. Para developer ini membeli tanah tersebut dengan PPJB setelah itu baru dibuatkan AJB nya, dikarenakan seorang pembeli belum bisa atau sanggup membayar lunas harga dari tanah yang akan dibelinya tersebut. Jadi faktor ini cukup berpengaruh terkait hal tersebut.

2. Finansial/keuangan, ini sudah pasti berpengaruh terhadap cepat/lamanya pembayaran yang dilakukan oleh orang yang ingin membeli.

3. Faktor manusia atau karakter dari pembeli, faktor ini juga menjadi salah satu faktor penting dan cukup berpengaruh dalam hal jual beli. Kita sebagai seorang yang akan menjual harus bisa memahami karakter dari calon pembeli, apakah dia mampu dan mau untuk membayar harganya atau tidak. 
Selaku Notaris/PPAT, ada beberapa faktor yang juga mempengaruhi peralihan hak milik atas tanahyang pembayarannya belum lunas, salah satunya yaitu faktor harga, faktor harga memang berpengaruh karena penting bagi notaris/PPAT menjamin agar tidak ada masalah yang akan timbul dikemudian haribagikeduabelahpihakdanPPATitusendiri.Berarti kesepakatan yang dibuat oleh kedua belah pihak terkait dengan harga tanah bisa saja sangat besar jadi metode pembayarannya tidak bisa dilakukan dalam satu waktu.

Beberapa faktor yang sudah dijelaskan di atas memang benar-benar berpengaruh terkait dengan adanya PPJB yang belum lunas, dan sebagai seorang notaris/PPAT juga memiliki tanggungjawab sampai dilakukannya pelunasan terkait pembayaran tanah tersebut sehingga setelah itu notaris/PPAT akan bisa mengurus terkait penerbitan sertifikat milik atas tanah tersebut dengan nama pemilik hak yang baru. Sampai akhirnya sertifikat itu terbit barulah tugas/tanggungjawab notaris itu selesai. Jadi disini dapat ditekankan bahwa tanggungjawab notaris/PPAT itu sangat besar, seorang notaris harus bisa memastikan bahwa setiap prosedur sudah berjalan dengan benar dan sesuai dengan peraturan jadi para pihak pun mendapat kepastian hukum terkait dengan perbuatan hukum yang dilakukannya.

Ada sebuah pernyataan bahwa Hukum Tanah Nasional adalah Hukum Adat berdasarkan pasal 5 UUPA. Artinya, kita selalu melibatkan Lembaga hukum beserta sistem hukum adatnya. Hukum adat yang digunakan tentunya hukum adat yang sudah disaneer/diperbaharui dan telah disempurnakan secara menyeluruh. Sehingga dapat disimpulkan bahwa yang dimaksud jual beli tanah menurut Hukum Tanah Nasional adalah pengertian jual beli tanah menurut hukum Adat. Kita juga pasti samasama mengetahui sumber dari Hukum Tanah Nasional kita yang berupa norma hukum yang tertulis dan juga tidak tertulis. Sumber dari hukum tertulis yaitu UUD NKRI 1945, Undang-Undang Pokok Agraria, Peraturan Pelaksanaan Undang - Undang Pokok Agraria serta peraturan lama yang tentunya masih berlaku hingga sekarang. Sedangkan untuk sumber hukum tidak tertulis yaitu berupa norma hukum adat itu sendiri serta hukum kebiasaan baru dan termasuk juga yurisprudensi. Selanjutnya definisi jual beli berdasarkan hukum Adat yaitu suatu perbuatan pemindahan hak atas suatu bidang tanah yang memiliki terang dan tunai. Terang itu berarti dalam prosesnya harus dilakukan dihadapan kepala adat, yang diposisikan sebagai pejabat dan tentunya menanggung keteraturan atau sahnya pemindahan dari hak tersebut. Tunai berati pemindahan hak milik atas tanah beserta pembayaran harganya dilakukan langsung serentak. Sehingga, tunai juga dapat diartikan bahwa harga tanah dibayar secara kontan dan/baru dibayarkan sebagian (tetap dianggap tunai). Jika pembeli belum membayar sisanya, maka sebagai penjual tidak bisa menuntut atas dasar terjadinya jual beli dari tanah tersebut, melainkan atas dasar hukum utang piutangnya.

\section{SIMPULAN DAN SARAN}

\section{Simpulan}

Pertanggungjawaban notaris sebagai pejabat umum saat pembuatan akta pengikatan jaul beli yaitu bertanggung jawab secara hukum administrasi, hukum perdata, hukum pidana dan kode etik profesi notaris. Semuanya, tentu, berdasarkan pada hubungan hukum yang terjadi antara PPAT dengan para pihak yang menghadap saat pembuatan akta tersebut. Pertanggungjawaban dari sanksi administrasi yaitu peringtan lisan, peringatan tertulis, pemberhentian sementara, pemberhentian dengan hormat bahkan sampai pemberhentian tidak hormat. Selanjutnya untuk sanksi perdata yaitu berupa penggantian biaya atau ganti rugi dan juga bunga. Sedangkan sanksi pidana yang dapat dipertanggungjawabkan kepada seorang notaris/PPAT adalah apabila penipuan itu bersumber dari notaris/PPAT itu sendiri untuk sanksi pidana bisa diberikan dengan meninjau dahulu apakah notaris/PPAT itu memenuhi isi rumusan dari tindak pidana yang disangkakan. Selain dari ketiga sanksi diatas, baik dari segi hukum adiminstrasi, perdata hingga pidana notaris/PPAT yang pastinya juga bertanggung jawab peenuh secara sadar terhadap kode etik notaris, yang juga membuat notaris/PPAT bertanggung jawab atas sanksi berupa yaitu: teguran, peringatan, skor, hingga pemecatan dari keanggotan dan pemberhentian dengan tidak hormat.

Akibat hukum yang timbul terhadap pengikatan jual beli yang belum lunas yaitu apabila notaris/PPAT ketika proses membuat akta melakukan suatu kesalahan yang terbukti sampai menimbulkan kerugian bagi para pihak/penghadap, maka dalam hal ini notaris/PPAT sebagai pejabat umum dapat dimintai pertanggung jawaban atas kelalaiannya yang telah diperbuatnya dan bentuk tanggungjawab nya itu ditujukan langsung kepada PPAT secara pribadi, dan akibat hukumnya dari peralihan hak milik atas sebidang tanah yang pembayarannya belum lunas yaitu tetap sah terkait jual 
beli akan tetapi jika pembayarannya tersebut belum dapat dilunasi dahulu maka peralihan terkait dengan hak nya bisa ditangguhkan.

\section{Saran}

Melalui penelitian ini diharapkan kepada pemerintah supaya selalu mengawasi dan tentunya lebih memperhatikan mengenai prosedur terkait peralihan hak milik atas sebidang tanah yang dibuat dihadapan Notaris/PPAT sehingga dalam setiap proses pengikatan jual beli dapat berjalan sesuai aturan/regulasi yang ada. Notaris/PPAT sebaiknya selalu memberikan informasi terkait hukum itu sendiri kepada pihak yang akan melaukan pengikatan jual beli sehingga bisa tercipta kepastian dan juga perlindungan hukum bagi semua pihak termasuk notaris/PPAT itu sendiri. Kemudian, Kepada masyarakat umum diharapkan memberikan data-data yang sebenar- benarnya kepada Notaris/PPAT dan tidak melakukan ingkar janji, sehingga tidak menimbulkan permasalahan.

\section{DAFTAR PUSTAKA}

Muyassar, Ali, D., \& Suhaimi. (2019). Pertanggungjawaban Hukum Notaris terhadap Pengingkaran Akta Jual Beli Tanah Bersertifikat oleh Pihak yang Dirugikan. Syiah Kuala Law Journal, 3(1), 147-166.

Rosadi, A. G. (2020). Tanggung Jawab Notaris Dalam Sengketa Para Pihak Terkait Akta Perjanjian Pengikatan Jual Beli (PPJB) Yang Dibuatnya. JCH (Jurnal Cendekia Hukum), 5(2), 243.

Santyaningtyas, A. C., \& Zubaidi, R. (2020). Role of Land Deed Officials in Legal Satisfaction Guarantee for Complete Systematic Land Registration. Jurnal Notariil, 5(1), 49-57.

Sujana, I. N., Renaya, I. N., \& Prapta, I. W. M. A. (2019). Legal Satisfaction Suspended By Land Deed Official that Does Not Meet the Minimum Price Standard for Purchasing Apartment for Foreigner In Indonesia. Jurnal Notariil, 4(2), 73-79.

Suratman, \& Philips Dillah, H. (2012). Metode Penelitian Hukum. Bandung: Alfabeta.

Wulandari, A. A. D. (2019). Tanggung Jawab Notaris Akibat Batalnya Akta Perjanjian Pengikatan Jual Beli Tanah Karena Cacat Hukum. Acta Comitas, 3(3), 436.

Undang-Undang Nomor 2 Tahun 2014 tentang Perubahan atas Undang-Undang Nomor 30 tahun 2004 tentang Jabatan Notaris. 